\title{
Radon Measurements in Soils along the Coast of Accra from Teshie to Nyanyano, Southeastern Ghana
}

\author{
Paulina E. Amponsah ${ }^{1,2}$, Aba B. Andam ${ }^{2}$, and Irene N. Akoto ${ }^{1}$ \\ ${ }^{I}$ National Nuclear Research Institute, Ghana Atomic Energy Commission, Legon-Accra, Ghana \\ ${ }^{2}$ Graduate School of Nuclear and Allied Sciences, Ghana Atomic Energy Commission, Legon-Accra, Ghana \\ Corresponding author: \\ P. E. Amponsah, National Nuclear Research Institute, Ghana Atomic Energy Commission, P. O. Box LG 80, \\ Legon-Accra, Ghana \\ E-mail:pekua2@yahoo.com
}

(received in May 2014; accepted in June 2015)

\begin{abstract}
A study has been undertaken along the coast of Accra (Teshie to Nyanyano) in the Greater Accra Metropolitan Area to investigate the emission of soil radon gas in the area using Lenin Resin (LR) 115 cellulose nitrate detectors. Twenty seven sampling points were considered for the investigation. A set of detectors were buried at a time and were replaced fortnightly for a period of 2 weeks. Three exposures were made at each location. Due to logistics constraints, the detectors were buried in phases over a period of 15 weeks. After the exposure period, the detectors were etched, air dried in the laboratory and the registered alpha tracks were counted using the Spark counter. The track density was calculated and the radon gas concentration was computed. The radon concentrations ranged from $1.40 \mathrm{kBqm}^{-3}$ to $282.87 \mathrm{kBqm}^{-3}$ for the period of monitoring. The average soil radon concentration measured during the period of the survey was $24.41 \mathrm{kBqm}^{-3}$. Local earthquakes of magnitude ranging from 1.1 to 2.8 on the Richter scale were recorded during the study. Continuous monitoring of the gas could confirm high emanation with the activity of the coastal boundary fault.
\end{abstract}

Keywords: Ghana, soil radon concentration, coastal boundary fault, seismic activity, radon gas emanation and faults.

\section{Introduction}

Radon in soils along the coast of Accra (Teshie to Nyanyano) has been measured to determine the level of the concentration in the largely dominated fishing area. The soil radon gas survey was conducted to establish the correlation, if any, between gas emanation and the activity of the coastal boundary fault, a major fault in the study area (Figure 1). Faults are known to be a perfect passageway for the migration of the gas. Soil gas radon concentrations have been used extensively to map active faults, as faults and fractures in the underlying rocks provide paths of high permeability and, therefore, serve as conduits for radon gas migration (Teng, 1980; Burton et al., 2004). High concentrations of the gas can also pose health hazards to inhabitants.

Radon $\left({ }^{222} \mathrm{Rn}\right)$ is one of the naturally occurring isotopes that can be used in geological, seismic and tectonic studies. It has a half-life of 3.8235 days and, therefore, can be used appreciably for such a study. The gas occurs in most soils and rocks due to the presence of small quantities of uranium and radium (its direct parent nuclides), and it can migrate for long distances through fractured rocks and overlying soils. When the gas is released into the soil, it decays and emits alpha particles. Alpha sensitive detectors buried in the soil at various depths are able to record the alpha particles produced by ${ }^{222} \mathrm{Rn}$ decay and its plate-out daughters (Burton et al., 2004; Amponsah et al., 2008).

\section{Fault systems in the study area}

South-eastern Ghana is bounded by 2 major fault zones, i.e. the Akwapim fault and the coastal boundary fault. The coastal boundary fault lies 
parallel with the coast of Ghana and is about $3 \mathrm{~km}$ offshore. The fault defines the contact between Jurassic and Tertiary sedimentary units and is believed to have developed during the Jurassic and continued to be active during Cretaceous and Tertiary times. The coastal boundary fault intersects the Akwapim fault at Nyanyanu, a coastal town near Accra where the investigation was carried out. The intersection is marked by intense shearing and fracturing at the beach (Blundell and Banson, 1975). Bacon and Banson (1979) attributed the seismicity of south-eastern Ghana to the level of activity of the Akwapim fault and the coastal boundary fault. The selected area is characterised by extensive fractures and faults. The area has also been investigated to be a seismically active zone in south-eastern Ghana (Amponsah, 2002).

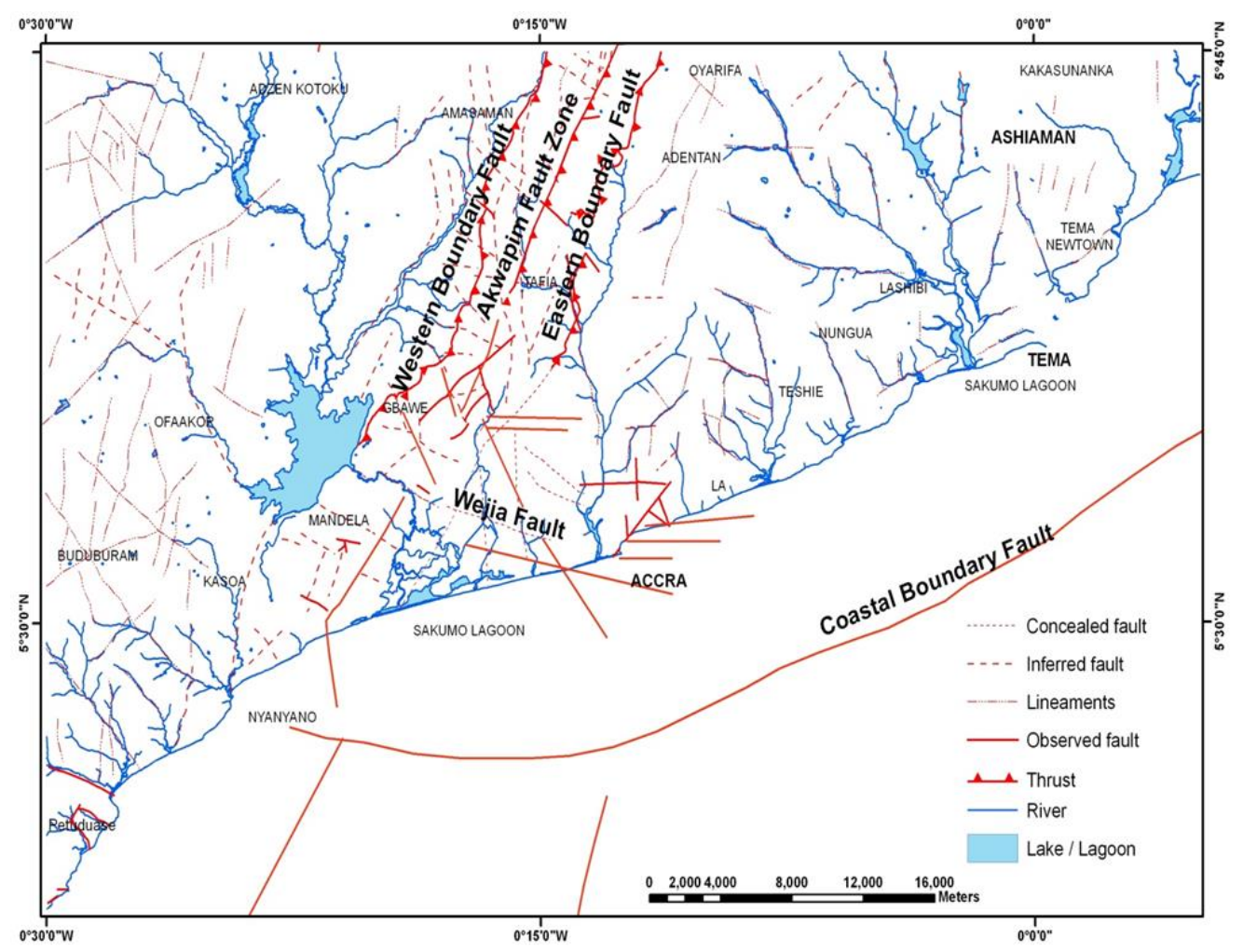

Figure 1. Fault map of the study area (modified from Muff and Efa, 2006).

\section{Materials and methods}

Measurement of the gas was done using a closed tube. Twenty seven (27) samples were employed at a sampling spacing of $500 \mathrm{~m}$. Lenin Resin (LR) 115 cellulose nitrate detectors manufactured by Kodak Pathé in France were used for the measurements. The dimensions of the detectors used were $2 \mathrm{~cm} \mathrm{x} 2 \mathrm{~cm}$. The detectors were fixed on wooden stoppers, fitted unto a polyvinyl chloride plastic tube (length $25 \mathrm{~cm}$ ) and buried in holes as shown in Figure 2. The tubes were buried at a depth of $75 \mathrm{~cm}$. The holes were covered at the top and the detectors were exposed for 2 weeks. After the exposure period, the detectors were removed and replaced with a new set. Three exposures were made at each location over a period of 15 weeks (14 April $2004-4$ August 2004). The detectors were detached from the stoppers and etched in a $2.5 \mathrm{M} \mathrm{NaOH}$ solution at a temperature of $60{ }^{\circ} \mathrm{C}$ for $110 \mathrm{~min}$. It was then rinsed in running water and the thin film of a plastic cover was peeled off and air dried in a laboratory. The registered alpha tracks were counted using the Spark counter.

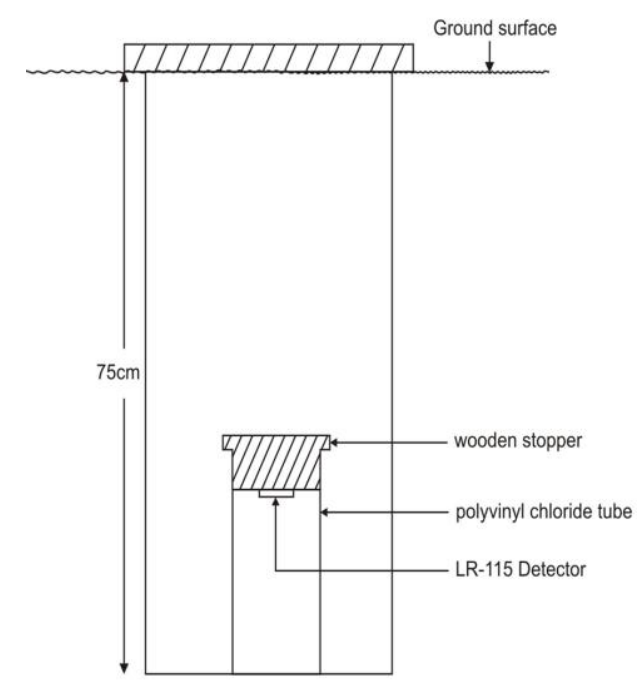

Figure 2. Set up for the radon gas measurement.

The radon data obtained were analysed. For each detector, 4 counts were made and the average value was taken. The track density was calculated using the average tracks counted and the area of the field of view of the electrode. The radon gas 
concentration was computed using the calibration factor $(k=0.29)$ obtained by the Ghana Atomic Energy Commission and verified in an intercomparison exercise organised by the Environmental Protection Agency of the United States of America and the International Atomic Energy Agency (Oppon et al., 1999).

\section{Results and discussion}

The radon concentrations registered during the period of monitoring ranged from $1.40 \mathrm{kBqm}^{-3}$ to $282.87 \mathrm{kBqm}^{-3}$. The average soil radon concentration measured during the period of the survey was 24.41
$\mathrm{kBqm}^{-3}$. Table 1 shows the radon concentrations of the 3 sets of detectors exposed. Detector number 15 registered $282.87 \mathrm{kBqm}^{-3}$ during the first round of exposure, but much less during the second and third exposures. This could be attributed to moisture from rain water, which prevented the passage of the gas. It rained during the period when the second and third detectors were exposed (GMSD, 2004).

Earthquakes of magnitude ranging from 1.1 to 2.8 on the Richter scale were located in the area during the study (Table 2) (Amponsah et al., 2008). Continuous monitoring of the gas could ascertain the correlation between gas emanation and seismic events.

Table 1. Radon concentration of 3 sets of detectors exposed (14 April-4 August 2004).

\begin{tabular}{|c|c|c|c|c|c|}
\hline Detector number & Set 1 & Set 2 & Set 3 & Mean & Standard deviation \\
\hline & \multicolumn{4}{|c|}{ Concentration $/ \mathrm{kBqm}^{-3}$} & \\
\hline 1 & $37.00 \pm 0.008$ & $2.63 \pm 0.002$ & $9.54 \pm 0.004$ & $16.39 \pm 0.005$ & 14.85 \\
\hline 2 & $27.72 \pm 0.007$ & $17.24 \pm 0.006$ & $14.51 \pm 0.005$ & $19.82 \pm 0.006$ & 5.70 \\
\hline 3 & $102.84 \pm 0.014$ & $6.29 \pm 0.003$ & $11.91 \pm 0.005$ & $40.35 \pm 0.007$ & 44.25 \\
\hline 4 & $29.12 \pm 0.007$ & $5.32 \pm 0.003$ & $41.65 \pm 0.009$ & $25.37 \pm 0.003$ & 15.07 \\
\hline 5 & $5.73 \pm 0.002$ & $7.09 \pm 0.004$ & $5.43 \pm 0.003$ & $6.08 \pm 0.003$ & 0.72 \\
\hline 6 & $13.32 \pm 0.005$ & $2.12 \pm 0.002$ & $3.87 \pm 0.003$ & $6.43 \pm 0.005$ & 4.92 \\
\hline 7 & $26.98 \pm 0.007$ & $9.38 \pm 0.004$ & $12.10 \pm 0.005$ & $16.15 \pm 0.005$ & 7.73 \\
\hline 8 & $2.72 \pm 0.002$ & $1.56 \pm 0.002$ & $6.26 \pm 0.003$ & $3.51 \pm 0.002$ & 2.00 \\
\hline 9 & $282.87 \pm 0.023$ & $29.69 \pm 0.008$ & $33.20 \pm 0.795$ & $115.25 \pm 0.275$ & 118.53 \\
\hline 10 & $31.12 \pm 0.008$ & --- & $15.09 \pm 0.005$ & $23.10 \pm 0.007$ & 8.01 \\
\hline 11 & $64.37 \pm 0.011$ & $15.38 \pm 0.005$ & $14.92 \pm 0.005$ & $31.55 \pm 0.007$ & 23.20 \\
\hline 12 & $11.28 \pm 0.005$ & $4.45 \pm 0.003$ & $14.53 \pm 0.053$ & $10.09 \pm 0.020$ & 4.20 \\
\hline 13 & $60.60 \pm 0.011$ & $5.07 \pm 0.003$ & $14.58 \pm 0.005$ & $26.75 \pm 0.006$ & 24.25 \\
\hline 14 & $6.98 \pm 0.004$ & $13.77 \pm 0.005$ & $35.92 \pm 0.008$ & $18.89 \pm 0.006$ & 12.36 \\
\hline 15 & $282.68 \pm 0.023$ & $12.87 \pm 0.005$ & $24.02 \pm 0.007$ & $106.52 \pm 0.012$ & 124.65 \\
\hline 16 & $27.44 \pm 0.007$ & $2.88 \pm 0.002$ & $11.74 \pm 0.005$ & $14.02 \pm 0.005$ & 10.16 \\
\hline 17 & $25.02 \pm 0.007$ & $20.60 \pm 0.006$ & $14.32 \pm 0.005$ & $19.98 \pm 0.006$ & 4.39 \\
\hline 18 & $23.25 \pm 0.007$ & $3.29 \pm 0.001$ & $14.63 \pm 0.528$ & $13.73 \pm 0.018$ & 8.17 \\
\hline 19 & $44.35 \pm 0.009$ & $19.85 \pm 0.006$ & $32.64 \pm 0.008$ & $32.28 \pm 0.008$ & 10.00 \\
\hline 20 & $4.96 \pm 0.003$ & $30.19 \pm 0.008$ & $4.32 \pm 0.003$ & $13.16 \pm 0.005$ & 12.05 \\
\hline 21 & $10.58 \pm 0.004$ & $10.55 \pm 0.004$ & $10.51 \pm 0.004$ & $10.55 \pm 0.004$ & 0.03 \\
\hline 22 & $6.52 \pm 0.004$ & $9.50 \pm 0.004$ & $21.15 \pm 0.634$ & $12.39 \pm 0.214$ & 6.31 \\
\hline 23 & $3.04 \pm 0.002$ & $1.40 \pm 0.002$ & $7.91 \pm 0.004$ & $4.12 \pm 0.003$ & 2.77 \\
\hline 24 & $42.53 \pm 0.009$ & $16.59 \pm 0.006$ & $46.78 \pm 0.009$ & $35.30 \pm 0.008$ & 13.34 \\
\hline 25 & $11.13 \pm 0.005$ & $4.91 \pm 0.003$ & $4.73 \pm 0.003$ & $6.92 \pm 0.004$ & 2.98 \\
\hline 26 & $60.84 \pm 0.011$ & $33.98 \pm 0.008$ & --- & $47.41 \pm 0.010$ & 13.43 \\
\hline 27 & $3.36 \pm 0.03$ & $6.55 \pm 0.004$ & $9.75 \pm 0.004$ & $6.55 \pm 0.013$ & 2.61 \\
\hline
\end{tabular}

--- Detectors were tampered with.

Research into the radon concentration in soils in Ghana is ongoing. There is, therefore, no standard or acceptable threshold value for the soil radon concentration in the country as reference information. However, the mean of the data set (as used in similar research studies) was used as the threshold or background value (Cuff, 2001; Wrixon et al., 1988; Rannou, 1989).

Radon risk maps made in Israel have categorised radon emissions below $10.00 \mathrm{kBqm}^{-3}$ as low emissions, from $10.00 \mathrm{kBqm}^{-3}$ to $50.00 \mathrm{kBqm}^{-3}$ as moderate and above $50.00 \mathrm{kBqm}^{-3}$ as high emissions (Vulcan and Shirav, 1996). All values higher than $50.00 \mathrm{kBqm}^{-3}$ were classified as anomalous in the study.

A plot of the concentrations of radon gas from the 3 sets of detectors exposed and the mean of the data set indicated detector positions 9 and 15 as having very high emissions (Figure 3 ). The high concentrations could be due to intense fracturing/faulting in the area. 


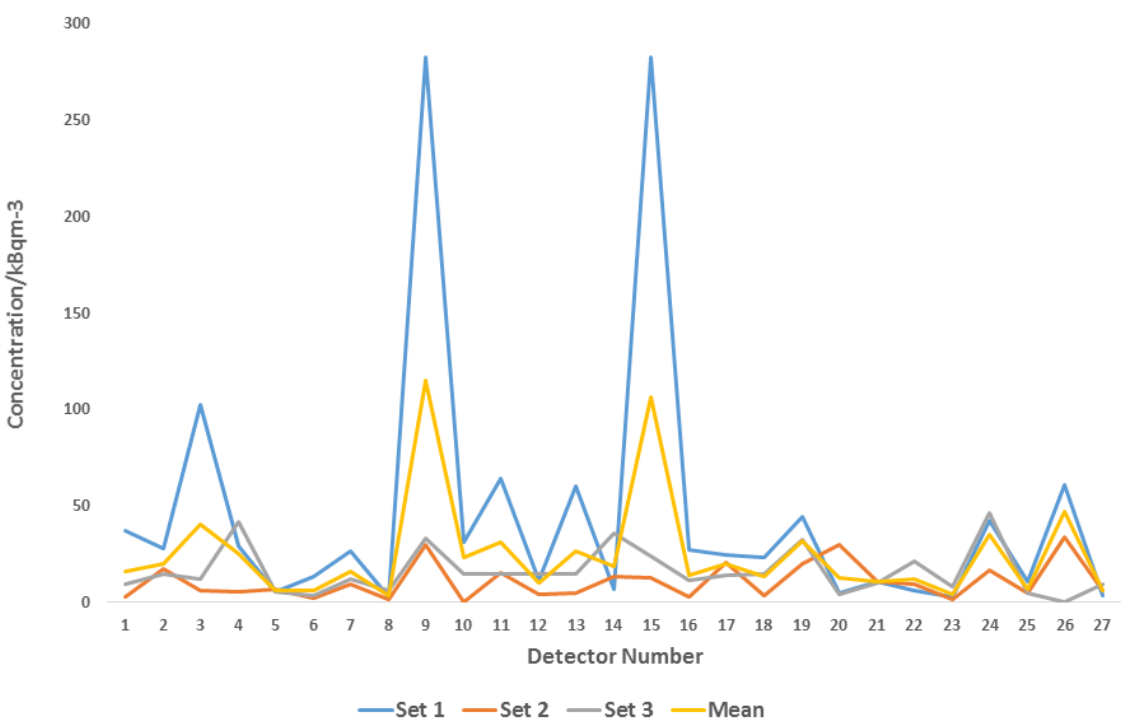

Figure 3. Soil radon concentration from Teshie to Nyanyano (set 1, set 2, set 3, and the mean).

Table 2. Seismic events recorded during the study by the Geological Survey Department, Ghana, in 2004.

\begin{tabular}{|c|c|c|c|c|c|}
\hline Date & Origin Time & Latitude, $^{\circ}$ & Longitude, $^{\circ}$ & Depth, km & "Magnitude (Richter scale) \\
\hline & $\mathrm{Hr}$ Min $\mathrm{Sec}$ & & & & \\
\hline 14-04-04 & $\begin{array}{lll}20 & 46 & 47.69\end{array}$ & $5.48 \mathrm{~N}$ & $0.71 \mathrm{~W}$ & --- & 1.5 \\
\hline $21-04-04$ & $\begin{array}{lll}18 & 11 & 59.49\end{array}$ & $5.82 \mathrm{~N}$ & $0.27 \mathrm{~W}$ & --- & 1.3 \\
\hline 24-04-04 & $\begin{array}{lll}18 & 54 & 43.36\end{array}$ & $5.82 \mathrm{~N}$ & $0.13 \mathrm{~W}$ & 58.7 & 2.8 \\
\hline 29-04-04 & $16 \quad 05$ & $5.66 \mathrm{~N}$ & $0.11 \mathrm{E}$ & --- & 1.1 \\
\hline $31-07-04$ & $\begin{array}{lll}06 & 43 & 36.40 \\
\end{array}$ & $5.55 \mathrm{~N}$ & $0.19 \mathrm{~W}$ & --- & 1.5 \\
\hline $28-08-04$ & $09 \quad 28$ & $5.91 \mathrm{~N}$ & $0.39 \mathrm{~W}$ & --- & 2.2 \\
\hline $31-08-04$ & 2046 & $5.85 \mathrm{~N}$ & $0.30 \mathrm{~W}$ & 21.8 & 2.1 \\
\hline
\end{tabular}

--- Uncertain depth.

\section{Conclusion}

The results of the study demonstrated that $55 \%$ of the area surveyed registered moderate emissions of the gas, $22 \%$ of the emissions were below the acceptable value of $50.00 \mathrm{kBqm}^{-3}$ and $23 \%$ were highly anomalous. The high emissions can be attributed to the presence of faults and fractures, which are common in the area. Monitoring soil radon gas in the area has actually helped to establish the fact that radon gas emission is high along faults and fractures. From the survey, it can be concluded that areas with anomalous emissions are the most likely places for seismic activity. This generally suggests that anomalous areas should be critically investigated before any more residential buildings are constructed as continuous inhalation of the gas can cause cancer of the lungs. The already built up areas should be properly ventilated in order not to expose occupants to any health hazards.

\section{References}

Amponsah, P., Banoeng-Yakubo, B., Andam, A., \& Asiedu, D. (2008). Soil radon concentration along fault systems in parts of Southeastern Ghana. Journal of African Earth Sciences, 51, 39 - 48. http://dx.doi.org/ 10.1016/j.jafrearsci.2007.11.004.

Amponsah, P. E. (2002). Seismic activity in relation to fault systems in southern Ghana. Journal of African
Earth Sciences, 35, 227 - 234. http://dx.doi.org/ 10.1016/S0899-5362(02)00100-8.

Bacon, M. \& Banson, J. K. A. (1979). Recent Seismicity of Southeastern Ghana. Earth and Planetary Science letters, 44, 43-46. http://dx.doi.org/10.1016/0012821X(79)90006-2.

Blundell, D. J. \& Banson, J. K. A. (1975). Interpretation of seismic reflection survey across the continental shelf of Accra and its bearing on earthquakes in the area. Report Geological Survey, 75(1), 1-7.

Burton, M., Neri, M., \& Condarelli, D. (2004). High spatial resolution radon measurements reveal hidden active faults on Mountain Etna. Geophysical research letters, 31, L07618. http://dx.doi.org/10.1029/2003GL019181.

Cuff, K. E. (2001). Soil-gas emanation in Long Valley Caldera, California. Eos, Transactions, American Geophysical Union, 82(47), Fall Meeting supplement.

Ghana Meteorological Services Department (GMSD). (2004). Weija and Accra Rainfall data for the year 2004.

Muff, R. \& Effah, E. (2006). Explanatory notes for the Geological map for urban planning. 1:50,000 of Greater Accra Metropolitan Area (pp. 1- 36).

Oppon, O. C., Aniagyei, H. M., Ofosu, G., \& Johnson, F. B. (1999). Report on Dunkonah radon gas studies (pp. 1-14). National Nuclear Research Institute, Ghana Atomic Energy commission.

Rannou, A. (1989). The bare detector and results of indoor radon survey in France. In: Proceedings of International workshop on radon monitoring in radio protection, environmental radioactivity and earth science (pp. 145 - 152). 
Teng, T. L. (1980). Some recent studies of ground water radon content as an earthquake precursor. Journal of Geophysical Research, 85, 3089 - 3099. http://dx.doi.org/10.1029/JB085iB06p03089.

Vulcan, U. \& Shirav, M. (1996). Radiometric maps of Israel-Partial contribution to the understanding of potential radon emanations. In Uranium exploration data and techniques applied to the preparation of radioelement maps. Proceedings of a Technical committee meeting held in Vienna.

Wrixon, A. D., Green, B. M. R., Lomas, P. R., Miles, J. C. H., Cliff, K. D., Francis, E. A., Driscoll, C. M. H., James, A. C., \& O'Riordan, M. C. (1988). Natural radiation exposure in U. K. dwellings. National radiological protection board report NRPB-R190, HMSO, London. 


\title{
Radono matavimai pietrytinės Ganos Akros pakrantės nuo Teši iki Nianiano dirvožemyje
}

\author{
Paulina E. Amponsah", ${ }^{1,}$ Aba B. Andam² ir Irene N. Akoto ${ }^{1}$ \\ ${ }^{1}$ Nacionalinis branduoliniu tyrimu institutas, Ganos atominès energetikos komisija, Legonas-Akra, Gana \\ ${ }^{2}$ Branduoliniu ir jungtiniu mokslu absolventu mokykla, Ganos atominès energetikos komisija, Legonas-Akra, \\ Gana
}

(gauta 2014 m. gegužès mèn.; priimta spaudai 2015 m. birželio mėn.)

Tyrimas buvo atliktas Akros pakrantèje (nuo Teši iki Nianiano) Didesniojoje Akros Metropolio teritorijoje, siekiant ištirti dirvožemyje esančio radono dujų emisijas, naudojant Lenino Resino (LT) - 115 celiuliozès nitrato jutiklius. Buvo pasirinkti dvidešimt septyni bandiniu paėmimo taškai. Visas jutiklių komplektas vienu metu buvo užkastas ị dirvožemi ir pakeistas po dviejų savaičių. Kiekviename taške buvo atlikta po tris bandymus. Dèl susisiekimo apribojimų, visi jutikliai buvo užkasti per ilgesni nei penkiolikos savaičių periodą. Po išlaikymo periodo jutikliai buvo išèsdinti, išdžiovinti oru laboratorijoje ir, naudojant Spark skaičiuotuvą, buvo užregistruoti alfa pėdsakai. Buvo apskaičiuotas pėdsakų tankis ir radono dujų koncentracija. Radono koncentracijos ribos stebejjimo periode buvo nuo $1,40 \mathrm{kBqm}^{-3}$ iki $282,87 \mathrm{kBqm}^{-3}$. Vidutiné per tyrimo laiką išmatuota dirvožemio radono koncentracija buvo $24,41 \mathrm{kBqm}^{-3}$. Tyrimo metu buvo fiksuojami vietiniai žemès drebėjimai, kurių dydis pagal Richterio skalę siekè 1,1-2.8 Nuolatinè dujų stebėsena galètų patvirtinti didelị dujų kilimą dèl pakrantės ribos poslinkio.

Raktiniai žodžiai: Gana, dirvožemio radono koncentracija, pakrantès ribos poslinkis, seisminis aktyvumas, radono dujų kilimas ir sprūdžiai. 